\title{
Landscape level analysis of disturbance regimes in protected areas of Rajasthan, India
}

\author{
P Hari Krishna ${ }^{1, *}$ C Sudhakar Reddy ${ }^{1}$, Randeep Singh $^{2}$ and C S Jha ${ }^{1}$ \\ ${ }^{1}$ Forestry and Ecology Group, National Remote Sensing Centre, Balanagar, Hyderabad 500 037, India. \\ ${ }^{2} G$ B Pant Institute of Himalayan Environment and Development, Almora 263 643, Uttarakhand, India. \\ *Corresponding author. e-mail: hariknrsa@gmail.com
}

There is an urgent need to identify the human influence on landscape as disturbance regimes was realized for prioritization of the protected areas. The present study has attempted to describe the landscape level assessment of fragmentation and disturbance index in protected areas of Rajasthan using remote sensing and GIS techniques. Geospatial analysis of disturbance regimes indicates $61.75 \%$ of the total PAs are under moderate disturbance index followed by $28.64 \%$ and $9.61 \%$ under low and high, respectively. Among the 28 protected areas - National Chambal WLS, Jaisamand WLS, Kumbhalgarh WLS, Sawai Man Singh WLS, Kailadevi WLS and Bandh Baratha WLS are representing high level of disturbance. The present study has emphasized the moderate to low disturbance regimes in protected areas, which infer low biotic pressure and conservation effectiveness of PA network in Rajasthan. The spatial information generated on PAs is of valuable use for forest management and developing conservation strategies.

\section{Introduction}

Due to ever-increasing demands of growing human population, now a major concern is on development of long-term strategies for sustainable natural resources management. The Convention on Biological Diversity calls for the establishment of a system of protected areas (PA) to conserve biological diversity. But many protected areas in the world are being degraded and in danger of losing the very values for which they were originally established (CBD 2004). The sample study of protected areas at global level has shown that $1 \%$ of PAs are secure in the long run (CBD 2004). Remote sensing and Geographical Information System techniques are becoming increasingly important to assess the change in forest ecosystems to prioritise the efforts of conservation (Salem 2003; Ambastha and Jha 2010; Pattanaik et al. 2010;
Roy et al. 2013). The advantage of integrating the spatial and non-spatial information can be effectively used in identification of conservation prioritization zones.

Spatial distribution of vegetation types and relevant drivers of anthropogenic factors work as one of the key inputs for geospatial analysis and helps in locating priority areas for conservation action and research (Turner 1987; Kiester et al. 1996). The ecosystem degradation is found to be associated with the degree of spatial fragmentation (Ludeke et al. 1990). Fragmentation of forests has serious consequences for biodiversity and the ecology of forests. Geospatial modelling of forest disturbance using fragmentation, landscape neighbourhood properties, biotic pressures and fire regimes provides spatial patterns of disturbance and facilitates prioritization of conservation measures and ecological integrity (Roy et al. 1997; Ambastha

Keywords. Protected areas; wildlife sanctuary; disturbance; fragmentation; remote sensing; Rajasthan; India. 


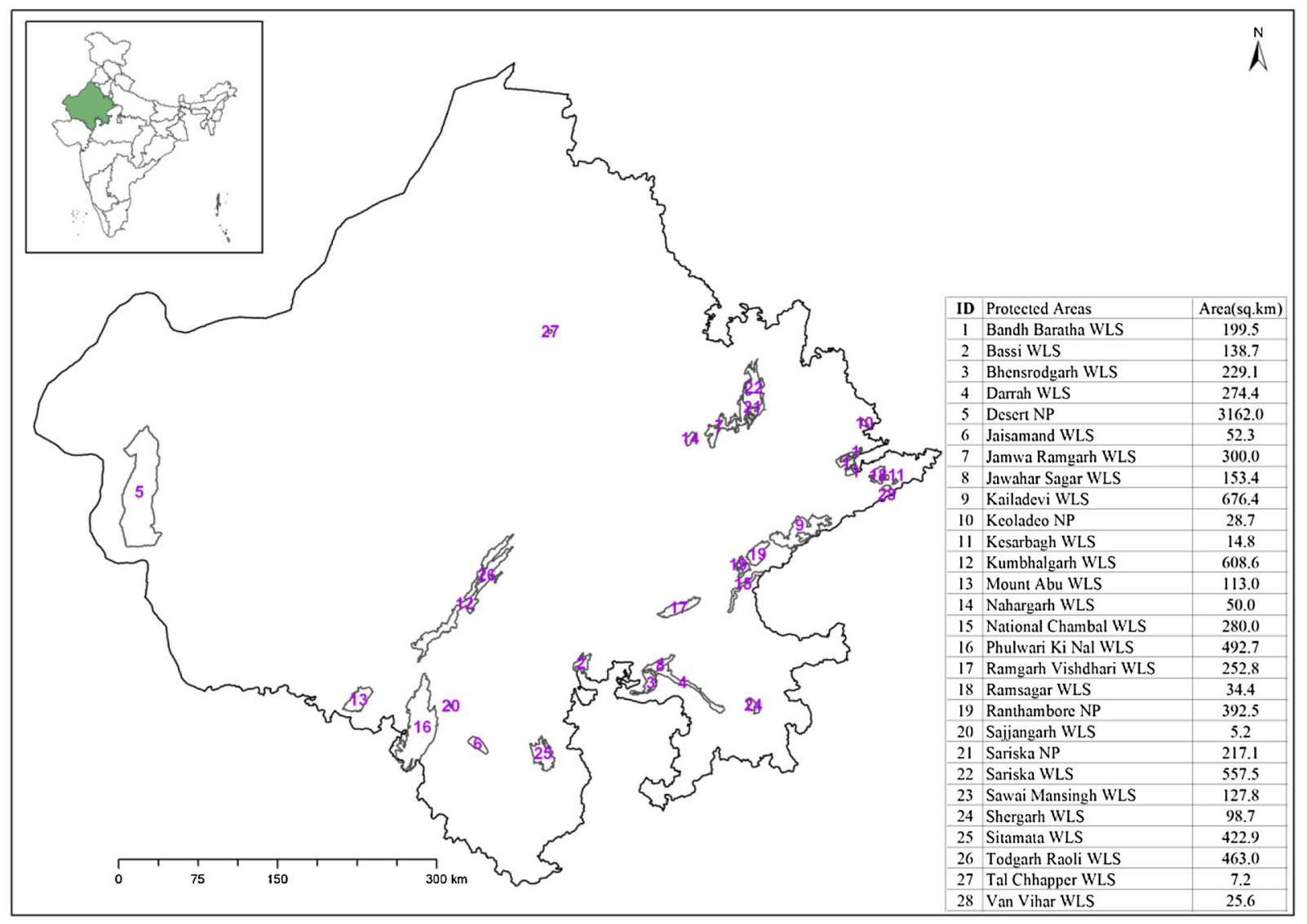

Figure 1. Study area.

and Jha 2010). National project on Biodiversity Characterization at Landscape Level (BCLL) using satellite remote sensing and GIS has been undertaken by the Department of Space and Department of Biotechnology as an important initiative to develop baseline database of forest landscapes of India (IIRS 2011).

India has 668 PAs (515 wildlife sanctuaries, 102 national parks, 47 Conservation Reserves and 4 Community Reserves). PAs of India cover $161,221.57 \mathrm{~km}^{2}$ represents $4.9 \%$ of the total geographical area (http://moef.nic.in/downloads/ public-information/protected-area-network.pdf).

There is a considerable requirement to identify the protected areas in India which are undergoing significant threat of deforestation, fragmentation and forest degradation. There is a need for an effective conservation strategy to extend the present PA network system in India (CBD 2004; Reddy 2008). To ensure the conservation effectiveness of protected areas, it is important to understand how the spatial distribution of disturbance regimes reached its current state. In this context, an urgent need to identify and analyze the human influence on landscape as disturbance regimes was realized for prioritization of the protected areas in Rajasthan.
Rajasthan is the largest state, occupying an area of about $342,239 \mathrm{~km}^{2}$ and covers $10.41 \%$ of geographical area in India. Being in arid and semi-arid part of India, the major proportion of forest cover in Rajasthan is occupied by dry deciduous forests (79\%) and thorn forests (16\%) (Reddy et al. 2011). Of the total forest area of $16,087 \mathrm{~km}^{2}$ (FSI 2011) in Rajasthan, $2.7 \%$ (minimum in 2006) to $10.9 \%$ (maximum in 2009) of forests were affected by fire during 2005-2010 (Hari Krishna and Reddy 2012). There are 28 protected areas in Rajasthan out of which 3 are national parks (NP) and 25 are wildlife sanctuaries (WLS) covering $2.8 \%$ of the total geographical area of state (Sakarwal and Ashok 2008) (figure 1). PAs of Rajasthan represent $5.8 \%$ of total PA extent of India.

\section{Materials and methods}

Indian Remote Sensing (IRS) P6 LISS-III multiseason datasets of 2005/2006 have been used for vegetation type and land use mapping on 1:50,000 scale (figure 2). Visual interpretation technique has been used. Field information on vegetation type, locality, aspect, slope, geographical location (using 


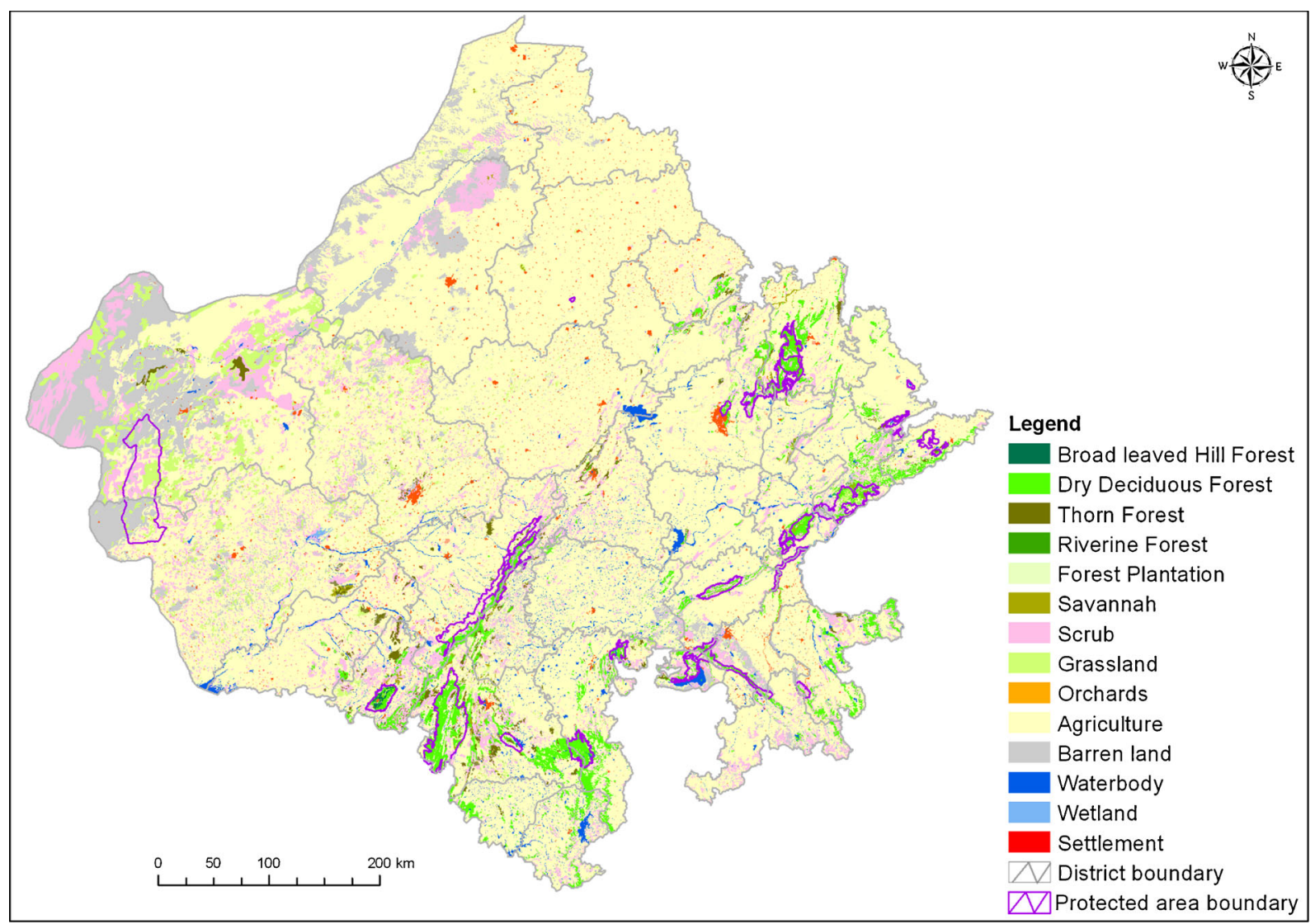

Figure 2. Vegetation type and land cover.

GPS) and signs of disturbance were recorded for classification and accuracy assessment. The classified map has been evaluated for classification accuracy based on 50 field derived points in each vegetation cover class. IRS P6 LISS-III data of 2010 have also been procured for carrying out the change assessment of vegetation types and land use. Dry season IRS P6 AWiFS data (March to May) have been used for mapping of forest burnt areas during 2005 to 2010. Landscape analysis has been carried out using methodology adopted by Roy and Tomar (2000). Spatial Landscape Analysis Model (SPLAM) developed at Indian Institute of Remote Sensing (IIRS), Dehradun was used (IIRS 2002). SPLAM is a program generated for the analysis of porosity, interspersion, fragmentation, juxtaposition and disturbance index. SPLAM uses a generic binary image as the input and the output is also written in the same format. A grid cell of $n \times n(n=500 \mathrm{~m}$ in the present study is based on national project on landscape level biodiversity characterization) is convolved with the spatial data layer with a criterion of deriving number of forest patches within the grid cell (IIRS 2011). Fragmentation analysis was carried out by recoding all the forested classes and nonforest classes.

\subsection{Fragmentation}

The forest type map will be reclassified into two classes, viz., forest and nonforest, resulting in a new spatial data layer. Fragmentation was computed as the number of patches of forest and nonforest types per unit area. A user grid cell of $n \times n$ (e.g., $n=500 \mathrm{~m}$ ) is convolved with the spatial data layer with criteria of deriving number of forest patches within the grid cell. Using a moving window approach, an output layer with patch numbers is derived and a look-up table (LUT) associated with this is generated, which keeps the normalized data of the patches per cell in the range from 0 to 10 . The mathematical representation of the fragmentation is:

$$
\text { Frag }=f\left(n_{F} / n_{N F}\right),
$$

where Frag $=$ fragmentation; $n=$ number of patches; $F=$ forest patches; and $N F=$ nonforest patches.

Pixels having fragmentation index value of 1 were categorized as low fragmentation; medium fragmentation was assigned to pixels having a value of 2 . All the pixels having values from 3 to 10 were categorized as high fragmentation areas. 


\subsection{Patchiness}

$$
P=\frac{\sum_{i=1}^{n} D i}{N} \times 100
$$

Patchiness is a measure of the density of patches of all types or number of clusters in a given mask. In other words, it is a measure of number of polygons over a particular area (Romme 1982) where $P$ is the patchiness, $D i$ is the dissimilarity value for the $i$ th boundary between adjacent cells and, $N$ is the number of boundaries between adjacent cells.

\subsection{Porosity}

Porosity is the measure of number of patches or density of patches within a particular type, regardless of patch size. Porosity will be calculated for only primary forest type or ecologically unique ecosystems, e.g., tropical wet evergreen, mangrove, shoals, etc. (Forman and Godron 1986)

$$
\mathrm{PO}=\sum_{i=1}^{n} \mathrm{Cp}_{i},
$$

where $\mathrm{Cp}_{i}$ is the number of closed patches of $i$ th cover class.

\subsection{Interspersion}

Interspersion is a count of dissimilar neighbours with respect to central pixel or measurement of the spatial intermixing of the vegetation types. This index is also used to represent the landscape diversity (shape of each category of cover divided by the boundary of the cover)

$$
I=\frac{\sum_{i=1}^{n} S F i}{n}
$$

where,

$$
S F i=\frac{\text { Edge }}{2 \sqrt{\pi * \text { Area } j}}
$$

where Edge $=$ the length of edge, in both $\mathrm{x}$ and $\mathrm{y}$ directions and Area $j=$ Area of $j$ th polygon formed by groups in $i$ th cover class.

For determination of interspersion a convolution window of $3 \times 3$ pixels will be used with the forest type map to compute the number of dissimilar pixels in the nearest neighbourhood. The computation is performed in an interactive mode through the entire spatial layer to derive an output interspersion layer. A normalised LUT is made in the range of $0-10$.

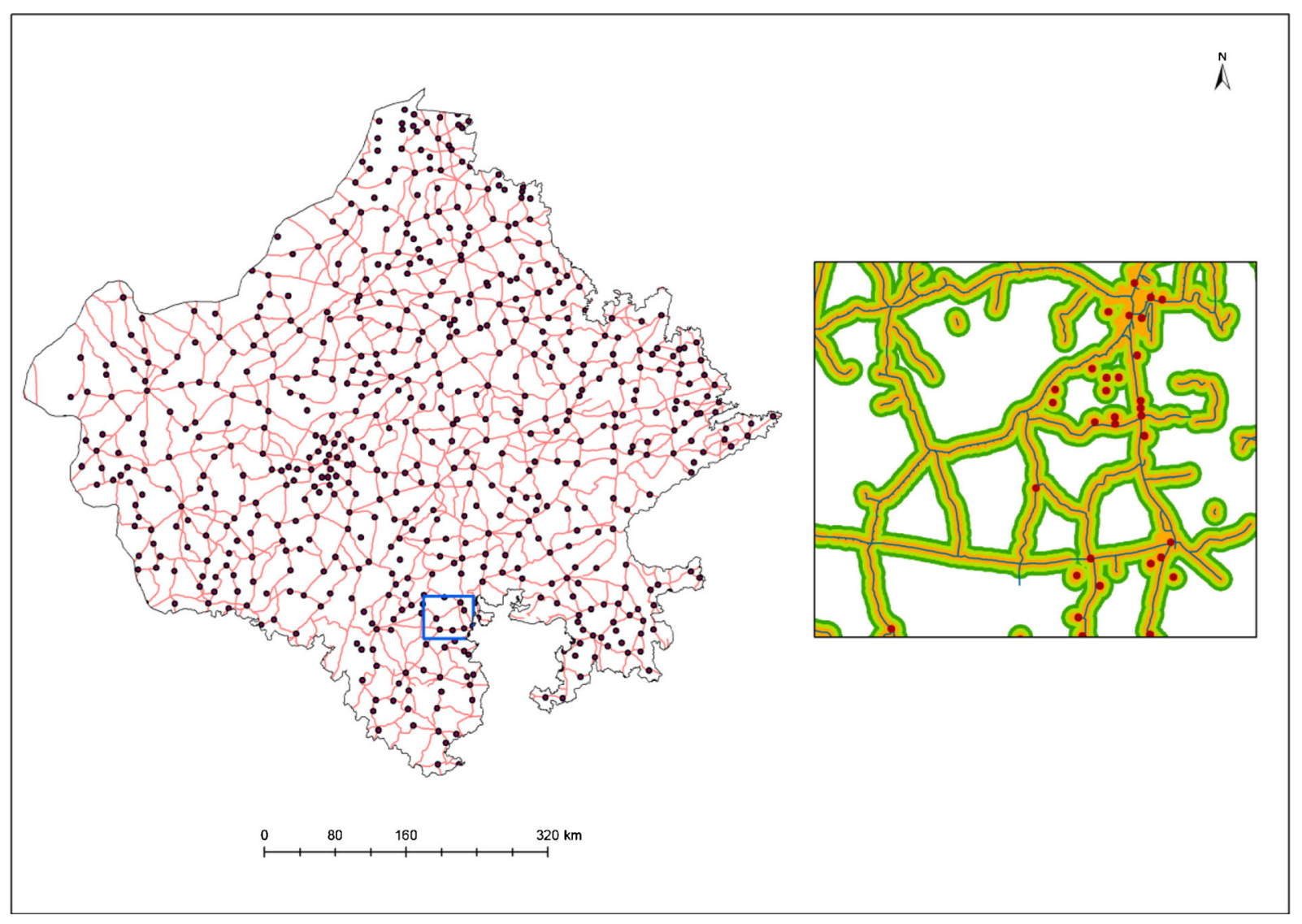

Figure 3. Proximity of road and settlement. 


\subsection{Juxtaposition}

Juxtaposition is defined as a measure of proximity of the vegetation. Its measurement mostly includes relative weightage assigned by the importance of the adjacency of two cover types for the species in question.

This parameter particularly helps in characterising the parameter porosity with respect to natural/unnatural vegetation. Since porosity can be understood as one of the important factors influencing the disturbance index, the added weightage through juxtaposition gives the correct perspective in ultimately deriving DI.

$$
J=\frac{\sum_{i=1}^{n} D i(J U X i)}{J U X_{\max }}
$$

where $J U X_{\max }$ is the average total weighted edge per habitat unit of Good habitat (Lyon 1983),

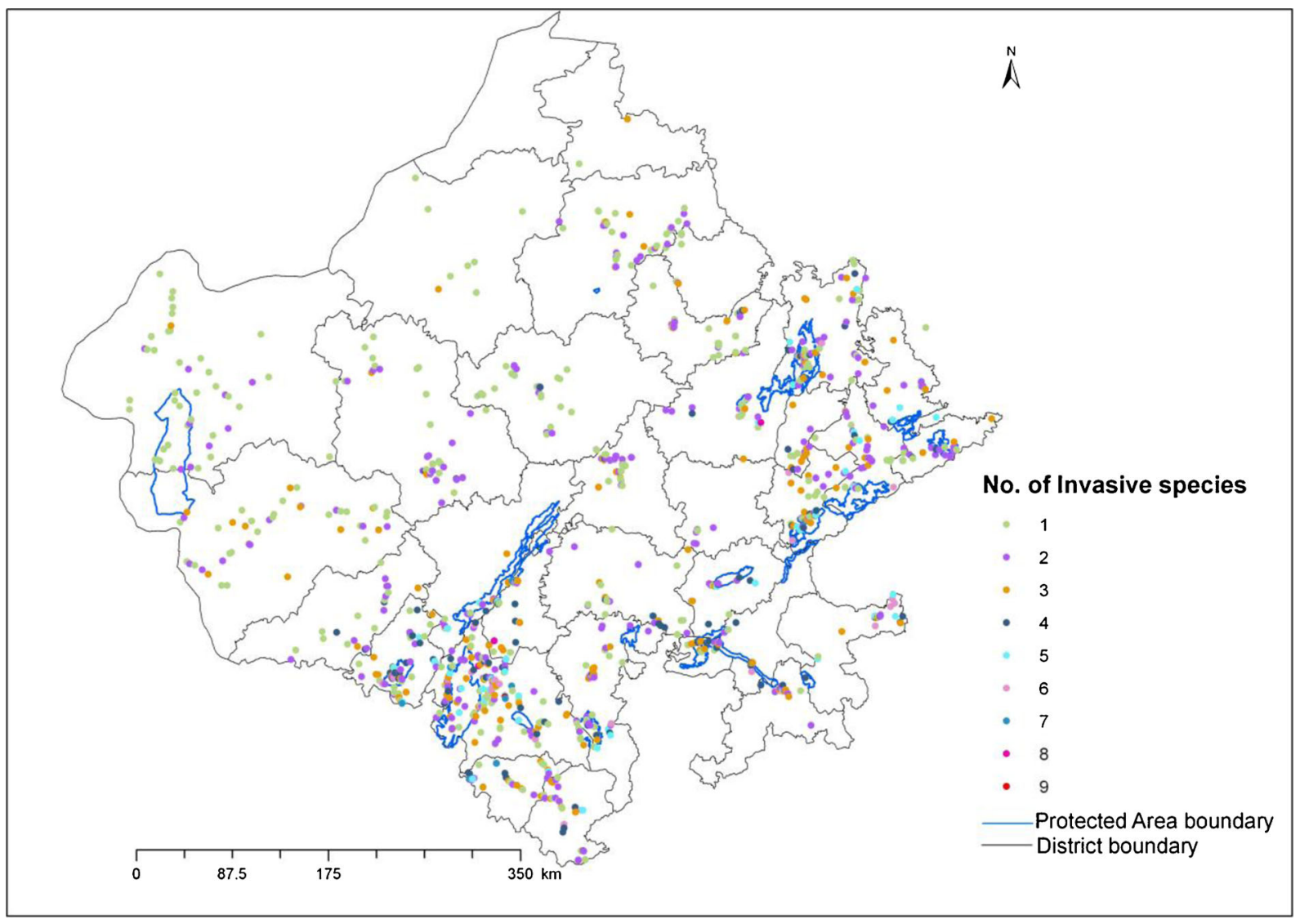

Figure 4. Invasive species distribution.

Table 1. Spatial extent of forest burnt area during 2005-2010 (area in $\mathrm{km}^{2}$ ).

\begin{tabular}{|c|c|c|c|c|c|c|c|c|c|c|c|c|c|}
\hline \multirow[b]{3}{*}{ Sl. no. } & \multirow[b]{3}{*}{ Protected area } & \multicolumn{12}{|c|}{ Burnt area } \\
\hline & & \multicolumn{2}{|c|}{2005} & \multicolumn{2}{|c|}{2006} & \multicolumn{2}{|c|}{2007} & \multicolumn{2}{|c|}{2008} & \multicolumn{2}{|c|}{2009} & \multicolumn{2}{|c|}{2010} \\
\hline & & Area & $\% *$ & Area & $\%$ & Area & $\%$ & Area & $\%$ & Area & $\%$ & Area & $\%$ \\
\hline 1 & Bassi WLS & 0.00 & 0.00 & 0.00 & 0.00 & 0.00 & 0.00 & 0.00 & 0.00 & 55.97 & 30.62 & 34.73 & 19.00 \\
\hline 2 & Jaisamand WLS & 0.00 & 0.00 & 0.00 & 0.00 & 0.30 & 0.21 & 0.00 & 0.00 & 0.27 & 0.18 & 15.47 & 10.61 \\
\hline 3 & Kumbhalgarh WLS & 0.00 & 0.00 & 0.00 & 0.00 & 0.00 & 0.00 & 0.99 & 0.11 & 11.49 & 1.32 & 10.52 & 1.21 \\
\hline 4 & Mount Abu WLS & 19.98 & 5.69 & 33.80 & 9.63 & 5.98 & 1.70 & 31.39 & 8.94 & 92.19 & 26.25 & 43.60 & 12.42 \\
\hline 5 & Phulwari Ki Nal WLS & 328.92 & 18.58 & 182.37 & 10.30 & 296.59 & 16.75 & 299.77 & 16.93 & 388.32 & 21.94 & 388.51 & 21.95 \\
\hline 6 & Sajjangarh WLS & 0.00 & 0.00 & 0.00 & 0.00 & 0.00 & 0.00 & 0.22 & 3.30 & 2.98 & 44.10 & 4.11 & 60.90 \\
\hline 7 & Sitamata WLS & 68.49 & 16.97 & 85.52 & 21.19 & 81.49 & 20.20 & 154.19 & 38.21 & 212.71 & 52.72 & 185.77 & 46.04 \\
\hline 8 & Tadgarh Raoli WLS & 0.00 & 0.00 & 0.00 & 0.00 & 0.00 & 0.00 & 0.00 & 0.00 & 28.77 & 6.85 & 0.00 & 0.00 \\
\hline & Grand total & 417.39 & 10.05 & 301.69 & 7.27 & 384.36 & 9.26 & 486.57 & 11.72 & 793.69 & 19.12 & 682.72 & 16.44 \\
\hline
\end{tabular}

$* \%$ refers to total geographic area of protected area. 
$D i$ is the edge desirability weight for each cover type combination, based on field data and $J U X i$ is the length of edge between combinations of cover types on either side of an edge.

\subsection{Biotic disturbance $(B D)$}

The basic information required here is the disturbance caused due to human interaction with forest and surroundings. Available maps (SOI or DCW) are used to extract information on roads, village/settlements, etc. A variable buffering with respect to the radial distance from the point of disturbance is performed by imposition of a condition that 'greater the distance lesser the weightage', in other words, weightage is set inversely proportional to the distance (figure 3).

\subsection{Disturbance index (DI)}

The disturbance surface was prepared as a combination of different landscape matrices, viz., fragmentation, porosity, juxtaposition, and interspersion. The spatial distribution of the anthropogenic/natural forces on the landscape was used to generate the spatial distribution of disturbance factors, viz., proximity to roads, villages, fire intensity and invasive alien species by using ground-based sampling data as well as ancillary databases. We have used the GPS-based locations of predominant invasive alien species (Prosopis juliflora, Lantana camara, Hyptis suaveolens, Cassia tora, Ageratum conyzoides, Cassia obtusifolia, Argemone mexicana, Ipomoea pes-tigridis, Tribulus terrestris) in protected areas for generating invasive species distribution map (figure 4). The disturbance index (DI) is computed by adopting a linear combination of the defined parameters on the basis of probabilistic weightage. The mathematical equation used for computing the disturbance index is as follows:

Disturbance index :

$$
\begin{aligned}
& \int\{\text { fragmentation, porosity, } \\
& \text { interspersion, proximity from } \\
& \text { disturbance sources, juxtaposition }\} \text {. }
\end{aligned}
$$

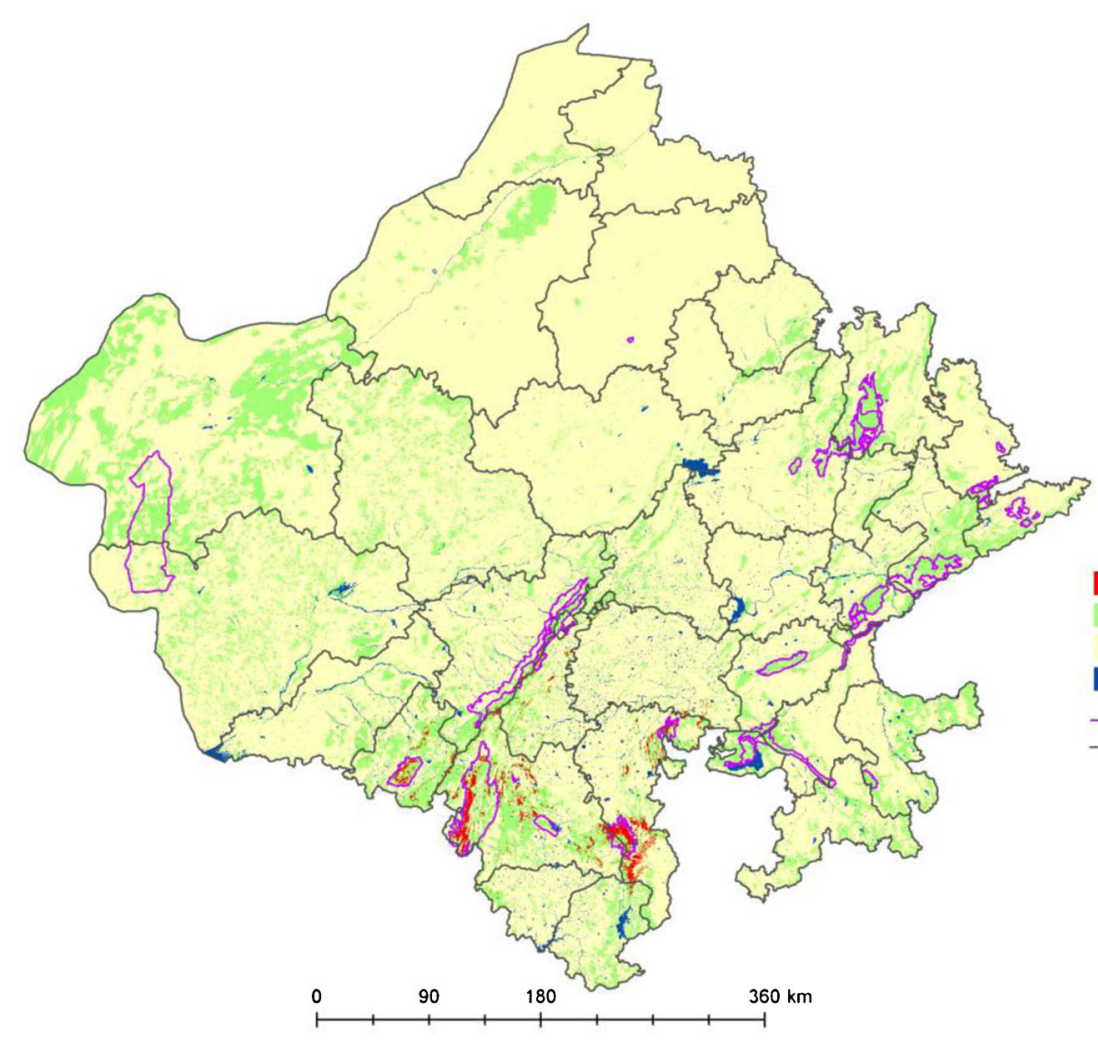

$\bigwedge^{N}$

Burnt area Vegetation cover Other land use Waterbodies Protected Area boundary District boundary

Figure 5. Forest burnt area (2005-2010). 
i.e.,

$$
\begin{aligned}
\mathrm{DI}= & \mathrm{W}_{1 \mathrm{i}} * F+\sum_{j}^{k}\left(\mathrm{~W}_{2 \mathrm{i}} * \mathrm{Pj}\right)+\mathrm{W}_{3 \mathrm{i}} * I \\
& +\mathrm{W}_{4 \mathrm{i}} * B+\mathrm{W}_{5 \mathrm{i}} * J
\end{aligned}
$$

where Wsi $(s=1,5 ; i=1,4)$ are the adaptive probabilistic weightages and $P j(j=1, k)$ are the derived porosity values.

Table 2. Accuracy assessment of classified vegetation type map.

\begin{tabular}{lcc}
\hline Class & $\begin{array}{c}\text { Producers } \\
\text { accuracy }\end{array}$ & $\begin{array}{c}\text { Users } \\
\text { accuracy }\end{array}$ \\
\hline Broad leaved hill forest & 92.31 & 96.00 \\
Dry deciduous forest & 93.75 & 96.15 \\
Thorn & 90.32 & 87.50 \\
Dry Savannah & 88.57 & 88.57 \\
Scrub & 86.67 & 92.86 \\
Grassland & 90.57 & 92.31 \\
Total & 91.10 & 93.09 \\
\hline
\end{tabular}

The disturbance index map has a range of $0-100$. The disturbance index was classified as (1) low (8-13); (2) medium (14-20); and (3) high $(21-73)$.

\section{Results and discussion}

No significant changes have been detected in spatial extent of vegetation and land cover of protected areas during 2005/2006 to 2010. However, forest fires as degradation indicator posing increasing threat in eight protected areas: Phulwari, Sitamata, Mt. Abu, Kumbhalgarh, Sajjangarh, Bassi, Jaisamand and Tadgarh Raoli (table 1) (figure 5). Recent study by Hari Krishna and Reddy (2012) has reported significant threat of forest fires in southern Aravallis of Rajasthan. The overall accuracy and kappa statistics of classified vegetation type map is $92.10 \%$ and 0.90 respectively. Accuracy ranged from $88 \%$ to $94 \%$ depending on the vegetation type (table 2 ).

\begin{tabular}{|c|c|c|c|}
\hline Protected area & Low & Medium & High \\
\hline Sajjangarh WLS & 16.82 & 65.97 & 17.22 \\
\hline Kesarbagh WLS & 30.59 & 52.62 & 16.79 \\
\hline Bandh Baratha WLS & 26.87 & 56.37 & 16.76 \\
\hline Ramsagar WLS & 0.00 & 85.85 & 14.15 \\
\hline Jawahar Sagar WLS & 50.70 & 35.43 & 13.88 \\
\hline National Chambal WLS & 1.48 & 84.68 & 13.84 \\
\hline Keoladeo Ghana NP & 52.64 & 34.36 & 13.00 \\
\hline Bhensrodgarh WLS & 30.02 & 58.16 & 11.82 \\
\hline Kailadevi WLS & 35.11 & 53.35 & 11.54 \\
\hline Kumbhalgarh WLS & 13.32 & 75.38 & 11.31 \\
\hline Van Vihar WLS & 33.68 & 56.45 & 9.87 \\
\hline Bassi WLS & 53.02 & 37.51 & 9.48 \\
\hline Jamwa Ramgarh WLS & 22.63 & 68.01 & 9.36 \\
\hline Darrah WLS & 44.69 & 46.80 & 8.50 \\
\hline Jaisamand WLS & 21.31 & 72.26 & 6.42 \\
\hline Sariska WLS & 53.77 & 41.05 & 5.17 \\
\hline Shergarh WLS & 49.15 & 46.12 & 4.73 \\
\hline Phulwari Ki Nal WLS & 42.20 & 53.23 & 4.58 \\
\hline Ranthambhore NP & 69.37 & 26.98 & 3.65 \\
\hline Ramgarh Vishdhari WLS & 36.86 & 59.59 & 3.55 \\
\hline Mount Abu WLS & 66.64 & 30.90 & 2.45 \\
\hline Sawai Man Singh WLS & 14.82 & 82.99 & 2.19 \\
\hline Desert NP & 38.23 & 59.85 & 1.92 \\
\hline Tadgarh Raoli WLS & 69.94 & 28.55 & 1.51 \\
\hline Sitamata WLS & 66.16 & 32.66 & 1.18 \\
\hline Nahargarh WLS & 43.43 & 56.04 & 0.53 \\
\hline Sariska NP & 92.51 & 7.03 & 0.46 \\
\hline
\end{tabular}

Table 3. Fragmentation status of protected areas of Rajasthan (\% of area). 
Table 4. Disturbance regimes in protected areas of Rajasthan (\% of area).

\begin{tabular}{|c|c|c|c|}
\hline Protected area & Low & Medium & High \\
\hline National Chambal WLS & 4.05 & 67.47 & 28.48 \\
\hline Jaisamand WLS & 8.66 & 67.64 & 23.70 \\
\hline Kumbhalgarh WLS & 35.70 & 43.65 & 20.65 \\
\hline Sawai Man Singh WLS & 11.21 & 71.25 & 17.54 \\
\hline Sajjangarh WLS & 42.00 & 41.24 & 16.76 \\
\hline Bandh Baratha WLS & 36.09 & 50.90 & 13.01 \\
\hline Jamwa Ramgarh WLS & 18.04 & 69.10 & 12.86 \\
\hline Nahargarh WLS & 13.62 & 73.87 & 12.51 \\
\hline Darrah WLS & 30.04 & 57.54 & 12.42 \\
\hline Kailadevi WLS & 16.65 & 71.04 & 12.31 \\
\hline Ramgarh Vishdhari WLS & 21.99 & 68.52 & 9.49 \\
\hline Phulwari Ki Nal WLS & 35.47 & 55.67 & 8.86 \\
\hline Keoladeo Ghana NP & 50.50 & 41.40 & 8.10 \\
\hline Van Vihar WLS & 15.51 & 76.44 & 8.05 \\
\hline Sariska WLS & 29.20 & 64.15 & 6.65 \\
\hline Bassi WLS & 30.11 & 63.73 & 6.16 \\
\hline Bhensrodgarh WLS & 23.11 & 71.05 & 5.84 \\
\hline Jawahar Sagar WLS & 45.55 & 48.86 & 5.59 \\
\hline Ramsagar WLS & 26.58 & 68.04 & 5.38 \\
\hline Mount Abu WLS & 34.21 & 60.58 & 5.21 \\
\hline Sitamata WLS & 37.26 & 58.56 & 4.18 \\
\hline Ranthambhore NP & 47.76 & 48.19 & 4.05 \\
\hline Kesarbagh WLS & 6.36 & 89.94 & 3.70 \\
\hline Desert NP & 34.38 & 62.81 & 2.81 \\
\hline Shergarh WLS & 45.55 & 52.04 & 2.41 \\
\hline Tadgarh Raoli WLS & 38.86 & 59.15 & 1.99 \\
\hline Sariska NP & 34.69 & 64.43 & 0.88 \\
\hline
\end{tabular}

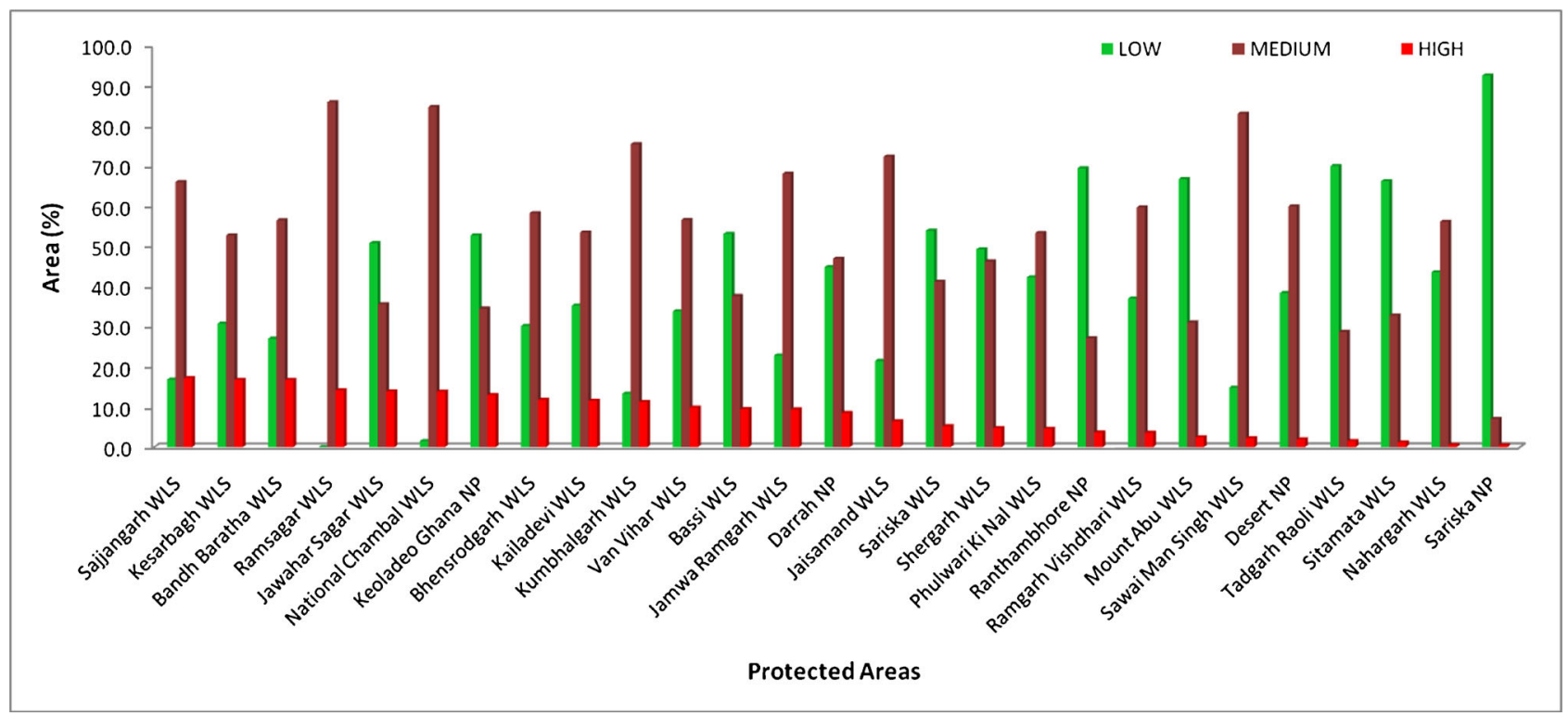

Figure 6. Fragmentation analysis in protected areas of Rajasthan. 
The geospatial analysis has identified distribution of fragmentation and disturbance zones across protected areas of Rajasthan. Our analyses indicate considerable areas of high to low fragmentation and high disturbance to low disturbance (tables 3 and 4). Overall observation of the fragmentation in all protected areas shows high fragmentation cover $7.99 \%$ of the total area. Spatially higher extents of fragmentation have been recorded in Sajjangarh WLS (17.22\%), Kesarbagh WLS (16.79\%), Bandh Baratha WLS (16.76\%), Ramsagar WLS (14.15\%), Jawahar Sagar WLS
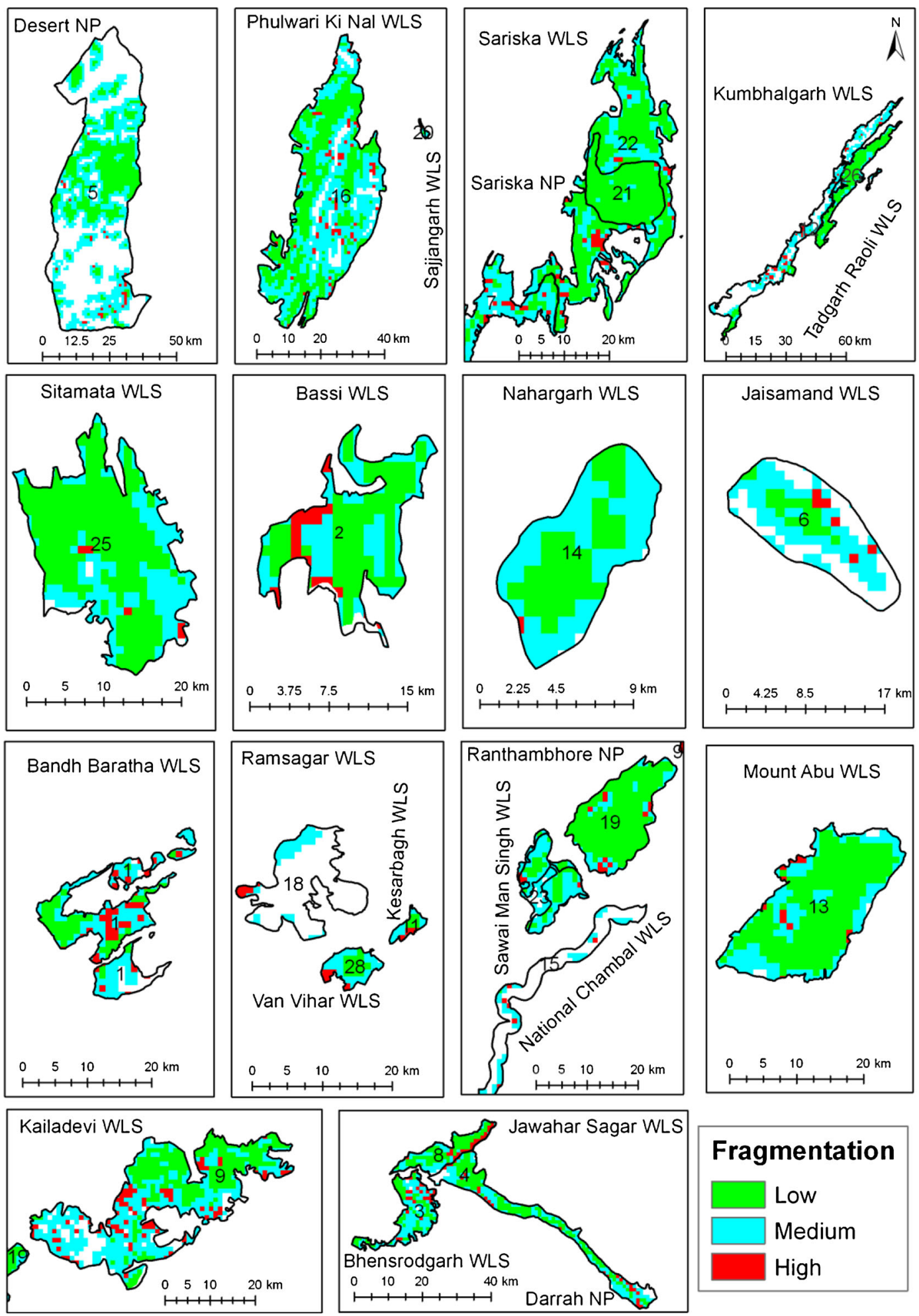

Fragmentation

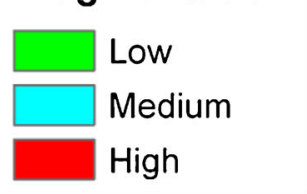

Figure 7. Fragmentation status in protected areas of Rajasthan. 


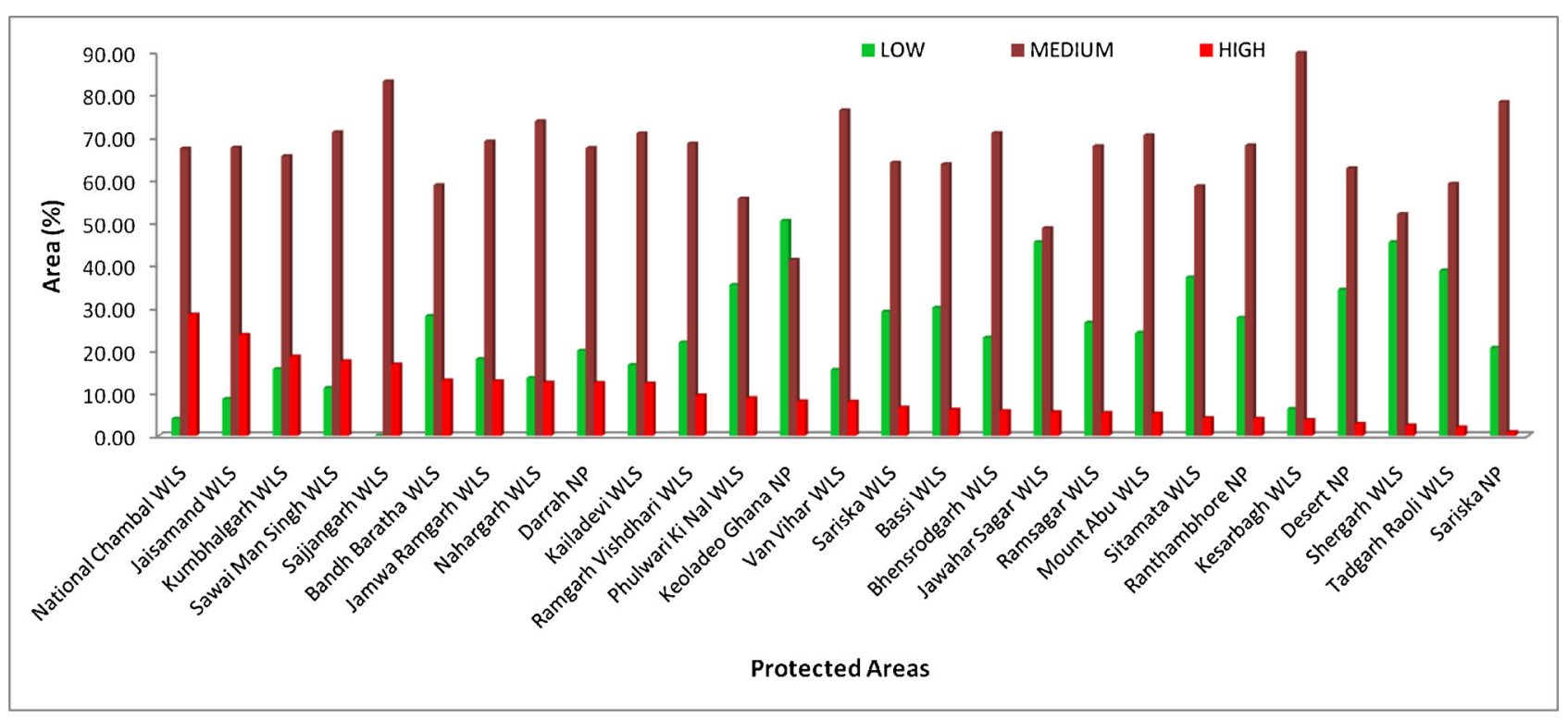

Figure 8. Disturbance index analysis in protected areas of Rajasthan.

(13.88\%), National Chambal WLS (13.84\%), Keoladeo Ghana NP (13\%), Bhensrodgarh WLS $(11.82 \%)$ and Kailadevi WLS $(11.5 \%)$ are under the high fragmentation category (figure 6). The low fragmentation has been recorded in Sariska NP $(0.46 \%)$, Nahargarh WLS $(0.53 \%)$, Sawai Man Singh WLS (2.19\%), Mt. Abu WLS (2.45\%) and Ranthambhore NP (3.65\%) (figure 7). Among the 28 protected areas, Sajjangarh is found to be smallest WLS and has higher fragmentation index.

Geospatial analysis of disturbance regimes indicates that $61.75 \%$ of the total PAs are under moderate disturbance index followed by $28.64 \%$ and 9.61\% under low and high, respectively (figure 8). Disturbance regimes across the individual PAs have been assessed and given in table 4. National Chambal WLS (28.48\%) shows maximum area under high disturbance regimes followed by Jaisamand WLS (23.70\%), Kumbhalgarh WLS (20.65\%), Sawai Man Singh WLS (17.54\%), Sajjangarh WLS (16.76\%), Bandh Baratha WLS (13.01\%), Jamwa Ramgarh WLS (12.86\%), Nahargarh WLS (12.51\%), Darrah (12.42\%) and Kailadevi (Keladevi) WLS (12.31\%) as compared to the other PAs (figure 8).

The vegetation in the areas of high disturbance index shows that these sites are affected by high edge density, recurrent forest fires, invasive alien species, porosity and occupied by open forests. The two tiger reserves and national parks of Rajasthan (i.e., Sariska and Ranthambhore) have higher percentage under low fragmentation and low level of disturbance indicates habitat suitability for biological needs of the flora and fauna. In Rajasthan, Sariska WLS, Ranthambhore WLS, and Sitamata
WLS areas with high terrain complexity represents high proportion of low to moderate disturbance index (figure 9).

National Chambal WLS, Jaisamand WLS, Kumbhalgarh WLS, Sawai Man Singh WLS, Kailadevi WLS and Bandh Baratha WLS, PAs show high level of disturbance but occupy less than $30 \%$ of area (figure 9). Desert National Park, the wildlife sanctuary of Thar Desert region represents more area under moderate disturbance. But intense grazing pressure and harvesting of grass for fodder is considered as a serious threat for Desert National Park (Singh and Singh 2006). Mt. Abu WLS, ecologically very unique with the presence of subtropical broad leaved hill forests indicates $5.21 \%$ of area under high disturbance, attributed to forest fires, abundance of invasive species (Lantana camara) and tourism.

The geospatial disturbance analysis in other protected areas of India reveals interesting results. Highly disturbed forest in Sunderbans of West Bengal is occupying $10.41 \%$ of forest area (Nandy and Kushwaha 2010). The study by Pattanaik et al. (2010) reported $13 \%$ of forests under high disturbance in Kuldiha wildlife sanctuary of Odisha. Subin et al. (2011) reported $2.76 \%$ area under high disturbance in Shendurney wildlife sanctuary of Kerala. Karanth et al. (2006) estimated $8-10 \%$ of the Bhadra Wildlife Sanctuary in high disturbance category of Karnataka.

\section{Conclusion}

The present study highlights the moderate to low disturbance regimes in protected areas of 

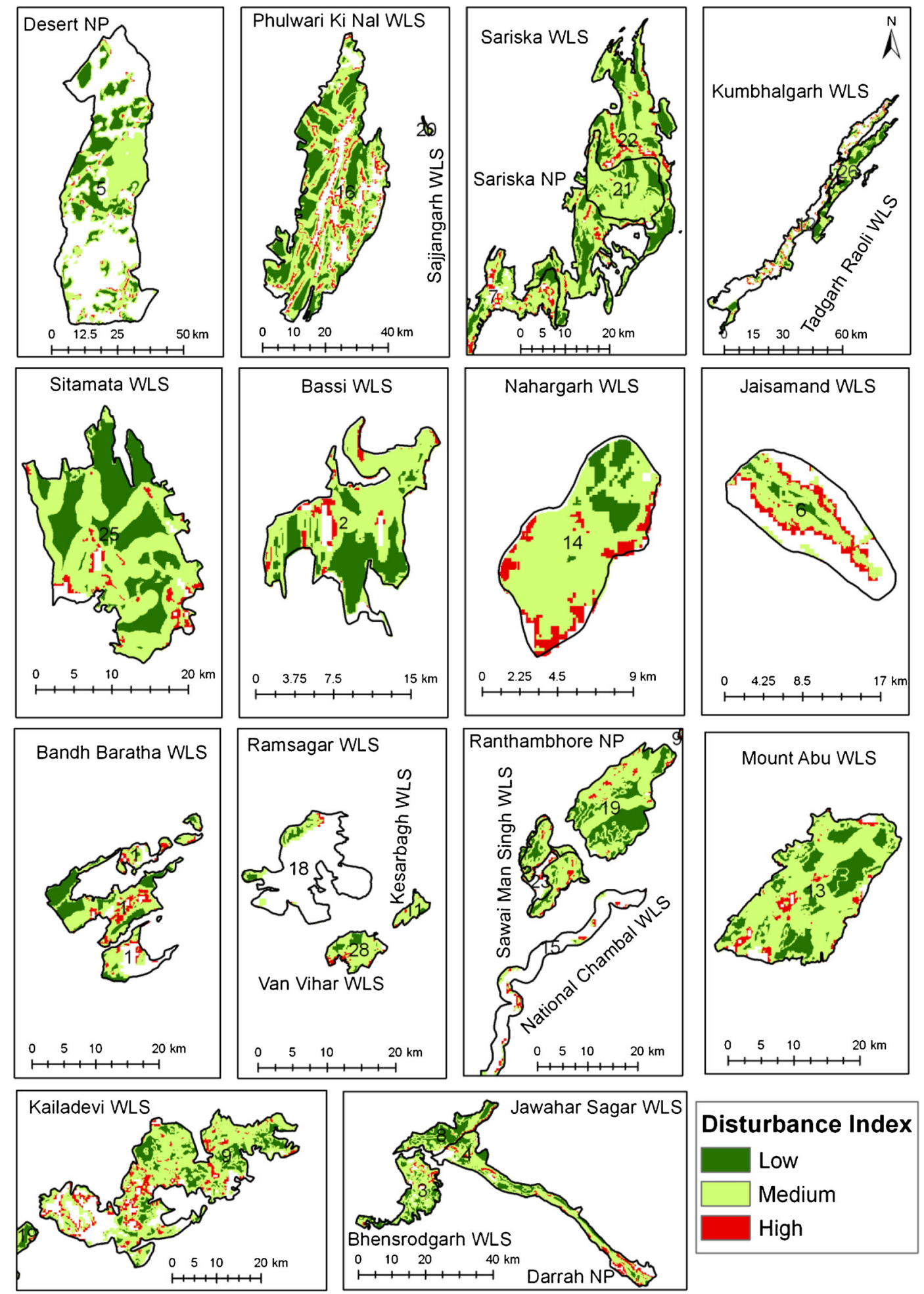

Figure 9. Disturbance index status in protected areas of Rajasthan.

Rajasthan, which implies low anthropogenic pressure and conservation effectiveness of protected area network in Rajasthan. The limitation of the study is non-inclusion of livestock pressure, people's dependency, socio-economic factors and species level threat. The landscape analysis using geospatial techniques provides an approach to understand the disturbance status of PA's, which is useful for forest resource management and conservation planning. Even though substantial progress has been made in protection of forests from biotic pressure, State Forest Departments need to initiate action on biological invasions which are considered the second worst threat to biodiversity. An 
effective strategic policy is also recommended to prevent forest fires in protected areas. There is a need for species level exploration studies to prioritise the long term conservation strategies in protected areas.

\section{Acknowledgements}

Authors are thankful to Dr V K Dadhwal, Director, NRSC and Dr P S Roy, Former Director, IIRS, Dehradun for suggestions and encouragement. The present work is carried out as part of national project on 'Biodiversity characterization at landscape level using satellite remote sensing and geographical information system' with financial support of Department of Space and Department of Biotechnology, Govt. of India.

\section{References}

Ambastha K R and Jha C S 2010 Geospatial analysis of Tamil Nadu Eastern Ghats forest types at landscape level with reference to fragmentation and species diversity; In: Biodiversity and Landscape Ecology, J. Indian Soc. Remote Sens. 38 453-463.

CBD 2004 Secretariat of the Convention on Biological Diversity, Biodiversity issues for consideration in the planning, establishment and management of protected area sites and networks. Montreal, SCBD, i-iv. (CBD Technical Series no. 15), 164p.

Forman T T and Godron M 1986 Landscape Ecology; John Wiley \& Sons, New York.

FSI 2011 State of Forest Report; Forest Survey of India, Ministry of Environment and Forests (MoEF), Government of India (GoI).

Hari Krishna P and Reddy C S 2012 Assessment of increasing threat of forest fires in Rajasthan, India using multitemporal remote sensing data (2005-2010); Curr. Sci. 102(9) 1288-1297.

IIRS 2002 Biodiversity characterisation at landscape level in north-east India using remote sensing and Geographical Information System; Indian Institute of Remote Sensing, Dehra Dun, 296p.

IIRS 2011 Biodiversity characterization at landscape level in northwest India and Lakshadweep islands using Remote Sensing and Geographic Information System; Indian Institute of Remote Sensing, Dehra Dun, 277p (ISBN: 978-81-211-0774-7).
Kiester A R, Scott J M, Csuti B, Noss R F, Buterfield B, Sahr K and White D 1996 Conservation prioritisation using GAP data; Conser. Biol. 10(5) 1332-1342.

Karanth K K, Curran L M and Reuning-Scherer J D 2006 Village size and forest disturbance in Bhadra Wildlife Sanctuary, Western Ghats, India; Biological Conservation 128 147-157.

Ludeke A K, Maggio R C and Reid L M 1990 An analysis of anthropogenic deforestation using logistic regression and GIS; J. Environ. Manag. 31 247-259.

Lyon J G 1983 Landsat-derived land cover classification for locating potential Kestrel nesting habitat. Photogramm; Engg. Remote Sens. 49(2) 245-250.

Nandy S and Kushwaha S P S 2010 Geospatial modelling of biological richness in Sunderbans; In: Biodiversity and Landscape Ecology, J. Indian Soc. Remote Sens. 38 431-440.

Pattanaik C, Reddy C S and Murthy M S R 2010 Geospatial modeling of biological richness in Kuldiha Wildlife Sanctuary of Orissa, India; J. Indian Soc. Remote Sens. 38 477-485.

Reddy C S 2008 Catalogue of invasive alien flora of India; Life Sci. J. 5(2) 84-89.

Reddy C S, Hari Krishna P and Ravikiran A 2011 Mapping the vegetation types of Rajasthan, India using remote sensing data; J. Environ. Res. Manag. 2(1) 1-9.

Romme W H 1982 Fire and landscape diversity in subalpine forests of Yellowstone National Park; Ecol. Monogr. 52 199-221.

Roy P S, Kushwaha S P S, Roy A, Karnataka H and Saran S 2013 Biodiversity characterization at landscape level using geospatial model; Anais XVI Simpósio Brasileiro de Sensoriamento Remoto - SBSR, Foz do Iguaçu, PR, Brasil, INPE, pp. 3321-3328 (http://www.dsr.inpe.br/ sbsr2013/files/p0140.pdf).

Roy P S and Tomar S 2000 Biodiversity characterisation at landscape level using geo-spatial modeling technique; Biological Conservation 95 95-109.

Roy P S, Tomar S and Jegannathan C 1997 Biodiversity characterisation at landscape level using satellite remote sensing; NNRMS Bulletin B-21 12-18.

Sakarwal S K and Ashok V 2008 Protected areas of Rajasthan. Conserving Biodiversity of Rajasthan; Himanshu Publications, pp. 16-30.

Salem B B 2003 Application of GIS to biodiversity monitoring; J. Arid Environ. 54 91-114.

Singh V and Singh M 2006 Biodiversity of Desert National Park, Rajasthan; Botanical Survey of India, Kolkata.

Subin K J, Alex C J, Santhosh K, Abin V and Madhu G 2011 Landscape Metric Modeling - a technique for forest disturbance assessment in Shendurney Wildlife Sanctuary; Environmental Research, Engineering and Management 4(58) 34-41.

Turner M G 1987 Landscape Heterogeneity and Disturbance; Springer-Verlag, New York. 